\title{
Lean Manufacturing Design to Reduce Waste in Customer Complaint Services Using Lean Principles in Coil Industry Companies, of Indonesia
}

\author{
Atep Afia Hidayat ${ }^{1}$, Muhammad Kholil ${ }^{2}$, Jakfat Haekal ${ }^{3}$, Wahyu Erka Sandra ${ }^{4}$ \& Dede Rukmayadi ${ }^{5}$ \\ ${ }^{1-4}$ Industrial Engineering Department, Faculty of Engineering \\ University of Mercu Buana, Indonesia \\ ${ }^{5}$ Industrial Engineering Department, Faculty of Engineering \\ Al Kamal Institute of Technology, Indonesia
}

\begin{abstract}
For the needs of the automotive industry, in maintaining customer satisfaction, the company provides customer complaint handling services completed within five days of the complaint being made. From 2017 to February 2020, the average time needed to resolve customer complaints is 9.99 days. This study aims to determine the type of waste that occurs, determine the factors that cause delay in determining the ideal time to resolve customer complaints. Therefore, the approach in this study uses the integer method DMAIC (Define, Measure, Analyze, and Improvement), VSM (Value Stream Mapping), and WAM (Waste Assessment Model). The integration of WAM and DMAIC methods can determine the types of waste that occur, namely Defect, Inventory, Overproduction, Motion, Transportation, Waiting, and Motion. The application of the DMAIC method is applied to determine the factors that cause waste, namely the markers used are easily lost and damaged, lack of customer knowledge of the needs, and availability of complaint samples. Other factors are, no customer complaint forms and guidelines, laboratory test work by one analyst, lack of analyst knowledge regarding SEM enlargement, the process with the same and repetitive activities. The analysis of data/information on complaints and laboratory test results is carried out simultaneously. In integrating VSM and DMAIC methods, the ideal time to resolve customer complaints can be determined to be 4.54 days, 0.82 days earlier than the company's target.
\end{abstract}

Keywords: DMAIC, VSM, WAM, Waste.

\section{INTRODUCTION}

Customer satisfaction is essential for the company because this can increase and maintain customer or consumer loyalty to the products produced by the company. In addition, according to Palacios et al. (2020), Consumer satisfaction is the essential factor in developing processes and building relationships with consumers. Therefore, companies need to maintain and increase customer satisfaction so that they can compete with other companies. In general, things that can affect customer satisfaction include good product quality and prices by the quality of the products offered. In contrast, according to Palacios et al. (2020), Customer satisfaction is greatly influenced by how the front liner provides services. In this case, the front liner has the meaning of a party in direct contact with customers or consumers, while service is all forms of service or services offered by the organization both before sales and after-sales.

In reality, companies are often faced with customer complaints that can interfere with customer satisfaction in the field. Complaints from customers can be product quality problems when customers use the goods they buy. Because of this, currently, various companies continue to compete to improve after-sales or after-sales services. This after-sales service aims to deal with product quality problems faced by customers for the products they consume and ensure that the same mistakes will not be repeated in the future. In dealing with product quality problems complained of by customers, the after-sales service performance assessment is seen in terms of speed and accuracy in dealing with quality problems complained of by customers so that that customer frustration can be maintained.

In its after-sales service, the company formed a section called Technical Service, which deals explicitly with quality problems complained of by customers. This is also done in the coil maker company where this research was conducted. 
A coil maker company is a manufacturing company that produces steel coils or coils for the needs of automotive companies as consumers. The company produces two steel coils, namely Cold Rolled (CR) and Galvannealed (GA). The following is an explanation of the two types of products, which can be seen in Figure 1.

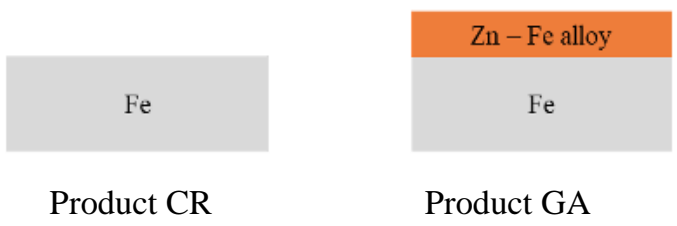

Figure 1 Product Pictures Cold Rolled (CR) \& Galvannealed (GA)

The two products will be used by customers or consumers, in this case, automotive companies to make car bodies, both as outer panels, parts of the car body that are exposed from the outside, such as the outer engine hood panels, front door outer panels, rear door outer panels, and so on, or the inner panel. This part is not exposed from the outside, such as the apron member panel, rocker panel, and so on.

In the Technical Service section of the coil maker company where this research was conducted, after-sales service in handling quality problems focuses on customer complaints in the production process, namely the press or stamping process, and includes companies appointed by consumers to perform cutting and blanking services. Coil into steel sheet, in this case, the company appointed by the customer to perform cutting and blanking services, is called a coil center company.

With the scope of the Technical Service section's work area, it is hoped that customer complaints regarding product quality problems can be well covered. Coil maker companies, in handling complaints about product quality problems, classify the complaints handled. The classification is based on the root cause of quality problems and whether or not a customer should report the root cause, and the precautions are taken to prevent recurring problems in the future. The classification can be seen in table 1 .

Table 1 Classification of Complaints from Coil Maker Companies

\begin{tabular}{|c|l|l|}
\hline No & $\begin{array}{c}\text { Classification of } \\
\text { Customer } \\
\text { Complaints }\end{array}$ & \multicolumn{1}{|c|}{ Explanation } \\
\hline 1 & Claim & $\begin{array}{l}\text { Quality problems caused by coil maker companies require reports } \\
\text { to consumers, and coil maker companies need to pay compensation } \\
\text { claims or cost penalties to consumers }\end{array}$ \\
\hline 2 & Complaint & $\begin{array}{l}\text { Quality problems caused by coil maker companies require reports } \\
\text { to consumers, and coil maker companies do not need to pay claim } \\
\text { compensation or cost penalties to consumers }\end{array}$ \\
\hline 3 & Information & $\begin{array}{l}\text { Quality problems caused by coil maker companies do not require } \\
\text { reports to consumers, and coil maker companies do not need to pay } \\
\text { claim compensation money or cost penalties to consumers }\end{array}$ \\
\hline 4 & Other & Quality problems caused by other than coil maker companies \\
\hline
\end{tabular}

Claim and complaint classifications are classifications of customer complaints that need special attention. Apart from the need for costs to be paid and reports to customers or consumers, this classification also determines how a customer or consumer satisfaction can be maintained. The sooner the reports to customers containing root causes of quality problems and preventive measures from these problems in the future. So it is hoped that customers or consumers will feel more at ease about the problems that are complained of can be resolved, which impacts maintaining customer satisfaction.

The form of customer complaint service that requires reports to customers, in this case, Claim and Complaint, the Company offers services in the form of providing reports related to root causes and steps to prevent quality problems to customers no later than five working days with a calculation of working hours of 8 hours per day; it can be said that the report can be completed and submitted to the customer for 40 hours. The Technical Service section will get information about complaints from customers and 
collect data and take quality problems samples needed to carry out investigations and analyzes related to quality problems that occur in consumers, where the data and samples will be used by the relevant department in this section Product Design \& Quality Control, Laboratory, and Manufacturing-Technology. Cooperation between these divisions is expected to find the root cause of the problem and determine the proper preventive steps to prevent the same problem from recurring in the future. The Technical Service division will later use the findings and preventive measures to create reports for customers.

The cooperation between these divisions is expected to be completed no later than five working days. It is still common to find that the completion process is more than the time targeted by the Company. This can impact the reduction and, even worse, namely, the loss of customer satisfaction with customer complaint service performance. To explain the unachievable time for resolving customer complaints related to quality problems that require reports, it can be seen in Figure 2

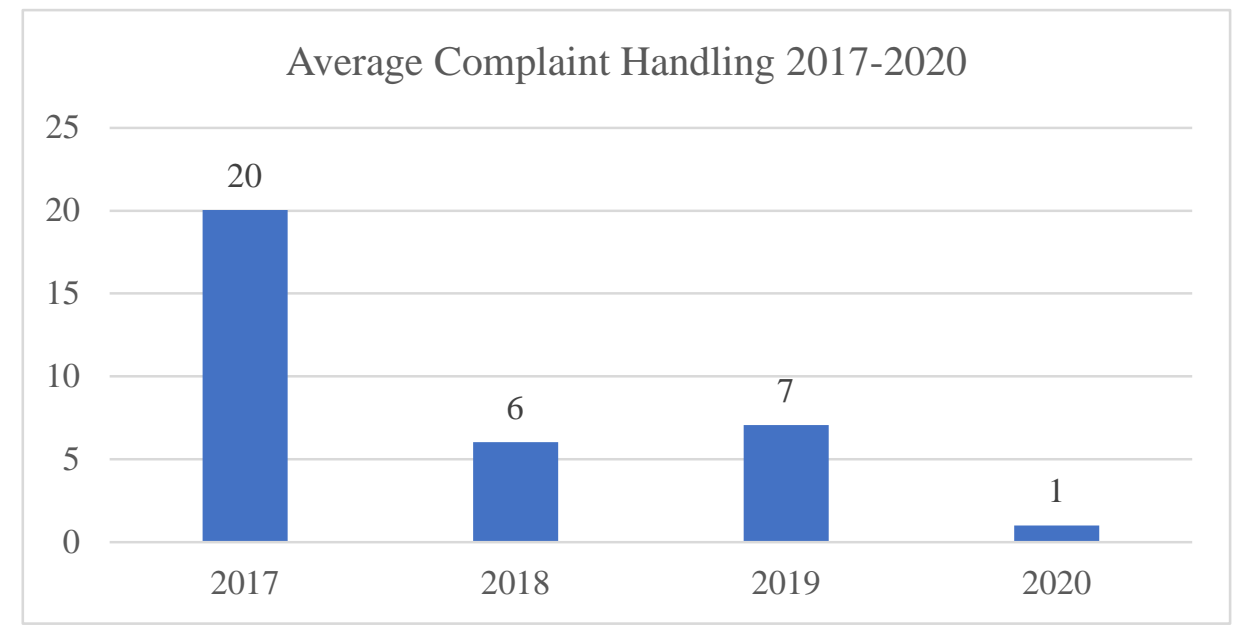

Figure 2 Average Completion Time for Customer Complaint Reports 2017 - 2020

From 2017 to 2020, the average time for complaint handling resolution was 9.99 days out of 80 complaints, with the condition in 2017 that the average complaint resolution was 20 days, in 2018 for six days, and in 2020 for one day with a new record. One complaint occurred in 2020; these customer complaints are a classification of customer complaints, claims, and complaints, which require a report to the customer. These complaints are complaints from customers forming abilities such as neck and crack, surface defects such as stains, roll marks, line marks, butsu, and quality problems caused by raw materials such as sliver and scab. In Figure 1.3, it can be seen that the time for resolving customer complaints has not yet reached the target set by the company, which is five working days. With this, it is necessary to analyze the causes of this happening, how repairs are needed, and the ideal time to complete the work.

Resolution of customer complaints. Lean, which is a continuous effort to eliminate waste and increase value-added products (goods and services) to provide value to customers (customer value) Gaspersz, 2007, is hoped to solve the problems faced. With the method used in lean, in this case, DMAIC, with stages such as Define it is expected to be able to determine problems from solving customer complaints, Measure measures critical aspects of improving the performance of customer complaints, Analyze by analyzing the data collected during research, improvement, and control how to control improvements so that they continue to run well.

Besides DMAIC, lean has other methods such as Value Stream Mapping (VSM) and Waste Assessment Model (WAM). According to Wilson (2010), Value Stream Mapping is a concept of lean manufacturing which shows a picture of all activities or activities carried out by the company. In this case, VSM is expected to describe the handling of customer complaints by coil maker companies. Wherefrom this description with the WAM method, it can show the waste that occurs in resolving customer complaint handling. According to Haekal (2020), the Waste Assessment Model is a model developed to simplify waste problems and identify them to eliminate waste. Using these three methods, the waste problems that occur and improve the performance of handling customer complaints.

\section{LITERATURE SURVEY}

\subsection{Handling of Complaints}

The complaint comes from the root word "complaint," which, according to KBBI, means an expression that comes out of feeling bad (because of suffering from something heavy, in pain, and so on). Meanwhile, according to (Tjiptono 2005) complaints are, 
complaints can be interpreted as an expression of dissatisfaction or disappointment, and according to (Barlow \& Moller, 1996), complaints are unfulfilled expectations. Due to complaints from customers regarding the quality of the products they consume, it is necessary to have handling that can resolve these complaints. Complaints expressed by customers are not only because of a sense of dissatisfaction and disappointment but also because of the customer's willingness to change the situation; in this case, the quality is better. Customer complaints are seen as a disaster that the company must face and an opportunity to get better and gain profits for the company if these complaints can be appropriately handled. According to Lebouef (1992), there are three reasons customer complaints can provide significant benefits:

1. The complaint identifies areas that need improvement.

2. Complaints are a second chance to provide service and satisfaction to disappointed customers.

3. Complaints are an opportunity to strengthen customer loyalty.

\subsection{Quality}

Quality has a broad definition depending on the defining point of view. According to (Gryna, 2007) a short definition of quality is customer satisfaction and loyalty. At the same time, the traditional definition of quality is the basis of the view that products and services must meet the requirements of those who use them. Ibrory (2005) mentions several definitions of quality as follows:

1. Quality means worthy of use.

There are two aspects to this definition, namely quality of design and quality of conformance. Quality of design is the level of quality; namely product specifications made based on the consumer's desires. Meanwhile, quality of conformance is how well a product meets the demand specifications with its design.

2. Quality is inversely related to variability

This means that the quality of the product will increase if the variability in the essential characteristics of a product decreases.

\section{3 .Lean}

Lean is a continuous effort to eliminate waste, increase value-added products (goods and / services), and provide value to customers (customer value) Gasperz (2008). In this case, the waste referred to is an activity or activity that is not needed or has no added value.

\section{RESEARCH METHODOLOGY}

In data processing and analysis, this study uses three methods for data processing so that the objectives of this research can be achieved; the three methods in processing the data are VSM (Value Stream Mapping), DMAIC (Define, Masure, Analyze, Improve, Control), and WAM (Waste Assessment Model).

Value Stream Mapping (VSM)

According to Wilson (2010), VSM is used to find waste in depicting the value stream; if the waste has been found, then the waste must be eliminated. VSM in this research is used to determine the type of waste that occurs and to determine the ideal time after identifying the cause of the waste that occurs, while the stages are as follows:

- Creating a Current Value Channel Mapping (CVSM)

The purpose of making CVSM is to describe the actual condition of the current process, which will be used to analyze the waste that occurs. The steps for creating a CVSM are as follows:

1. Determine the purpose of VSM.

2. Describe the sequence or flow of the process; at this stage, what needs to be considered is the determination of the start point and endpoint of the value stream created.

3. Describe the sequence or flow of material.

4. Describe the sequence or flow of information.

5. Calculating the required data such as lead time and taxt time.

6. Analyzing CVSM to determine the type of waste that occurs.

- Making Future Value Stream Mapping (FVSM)

In the CVSM that is made, the types of waste that occur will be analyzed and repaired. The defined improvements will be used to design and create the future value stream (fvsm). The FVSM that will be made has eliminated the waste found in CVSM, so at this stage the ideal time for handling customer complaints can be obtained. The steps for making FVSM are almost the same as CVSM, namely as follows:

- Describe the sequence or flow of processes.

- Describe the sequence or flow of material.

- Describe the sequence or flow of information.

- Perform data calculations such as lead time and taxt time from the results of the specified improvements.

DMAIC (Define, Measure, Analyze, Improvement, Control) 
International Journal of Engineering Research and Advanced Technology, Vol. 7, No.9, September -2021

DMAIC in this study is used to determine the causes of waste found in current conditions, DMAIC consists of 5 stages, as follows:

Define

At this stage, identifying and determining targets or targets for the types of waste found in the current actual conditions are carried out.

Measure

Calculations and measurements carried out at this stage are focused on waste which will become targets for improvement. Previously, data was collected that would be needed.

Analyze

At this stage the seban-effect diagram or Fishbone diagram will be used to determine the root causes and waste that occurs.

Improve

Improvements at this stage are carried out to improve the root causes of waste that occur which are obtained from the results of the analysis stage using fishbone diagram tools.

Control

This stage is carried out to control the process so that problems that the proposed improvement has handled do not occur again.

Waste Assessment Model (WAM)

According to Rawabdeh (2005) the Waste Assessment Model is a model developed to simplify the search for waste problems and identify them to eliminate waste. In this research, WAM will be integrated with the DMAIC method, namely at the Measure stage, where at the measure stage through the WAM method, the relationship size of waste and the amount of weight of waste that occurs can be measured. WAM has two stages of determining the amount of the waste relationship and the waste weight that occurs.

Waste Relationship Matrix (WRM)

WRM is a matrix used to determine the amount of the waste relationship that occurs. The matrix on WAM consists of rows and columns that represent the relationship of waste, WRM in this study aims to determine the size of the relationship between waste in handling customer complaints.

Waste Assessment Questionnaire (WAQ)

WAQ aims to measure the amount of waste that occurs by using a set of questions as many as 68 questions, and from the answers to questions from respondents, the weight of the waste that occurs will be measured.

\section{Research Steps}

In this study, research steps were made to help the research proceed by the method plan to be used during the research. This research step explains that there is an integration of the three methods used, namely DMAIC, VSM, and WAM. The VSM method will be integrated with DMAIC at the define stage to define and describe the current conditions using Current Value Stream Mapping. Future Value Stream Mapping, which obscures the condition plan after improvement, will be integrated with DMAIC at the improvement stage. Meanwhile, the WAM method will be integrated with the DMAIC method at the measuring stage, which is expected to be

\section{RESULT AND DISCUSSION}

Types of Waste in Handling Customer Complaints

In handling customer complaints, to determine the type of waste that occurs, the method used is the Waste Assessment Model (WAM) which is integrated with the DMAIC method at the Measure stage. Before processing data to determine the type of waste, data processing is carried out at the Define stage which is integrated with Current Value Stream Mapping (CVSM) to determine current conditions. The following are the results obtained at this stage. 


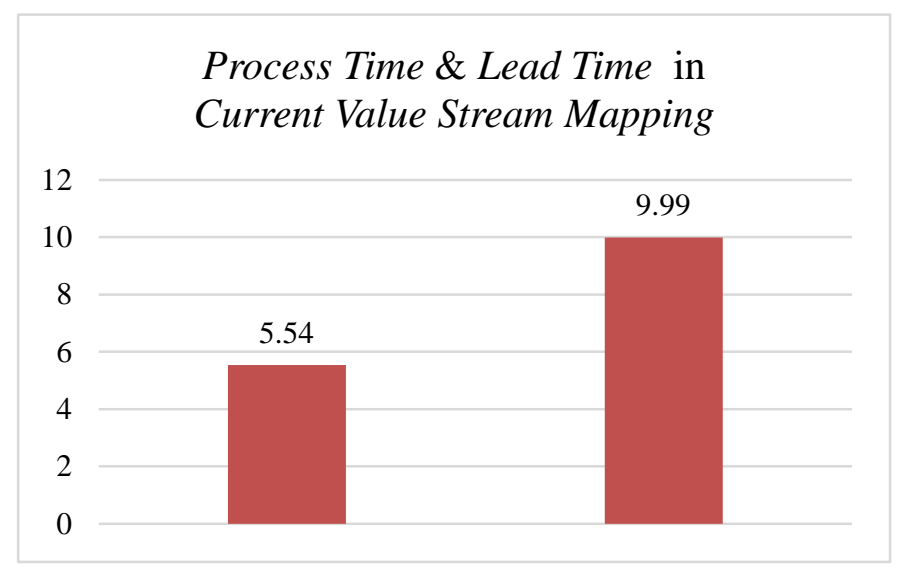

Figure 3 VSM Process Time and Lead Time

The graph above shows that the time for handling customer complaints, both process time and lead time, has not reached the company's target for handling customer complaints, which is a maximum of 5 days since the customer complaint is received. Not achieving the company's target indicates a waste that has occurred. At the DMAIC stage, namely a measure that is integrated with the Waste Assessment Model (WAM) method, the types of waste that occur in handling customer complaints can be seen, here are the results of data processing using the WAM method to determine the type of waste and the percentage of the weight of the waste that occurs.

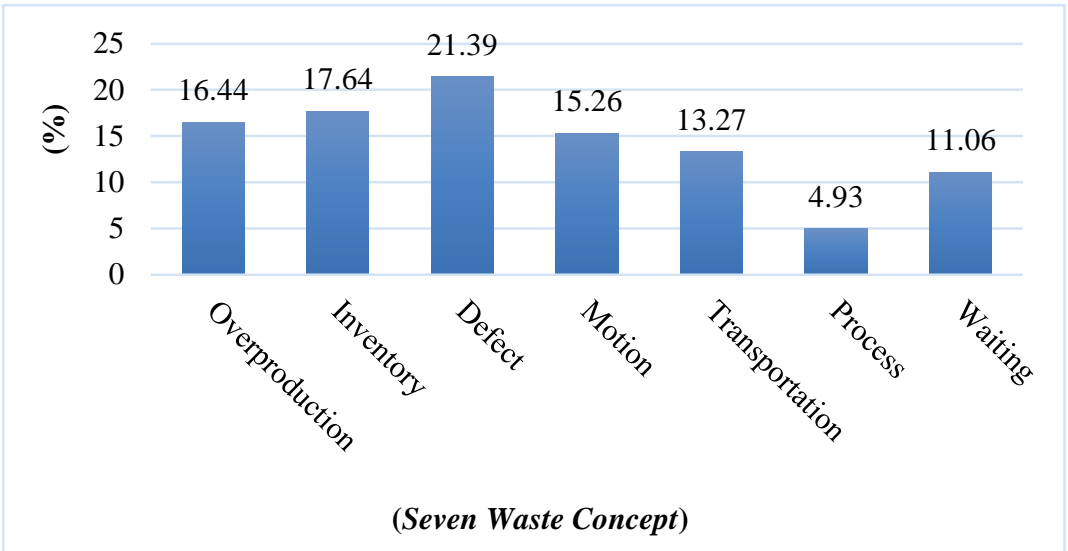

Figure 4Graph of Types of Waste and the Percentage of the Weight of the Waste Known by the WAM Method

Based on the Seven Waste Concept, the work of handling customer complaints at the coil maker waste company that has been detected by the application of the WAM method is Overproduction of $16.44 \%$, Inventory of $17.64 \%$, Defect of $21.39 \%$, Motion of 15, 26\%, Transportation $13.27 \%$, Process $4.93 \%$, and Waiting $11.06 \%$. With the three big wastes that occur, namely Defect, Inventory, and Overproduction. From the type of waste that occurs in the research conducted, data processing will be carried out to determine the factors that cause the waste that occurs.

\section{Factors that cause waste in handling customer complaints}

Based on the known waste types, data processing will be carried out to determine the factors causing the waste. The method used to determine the factors causing the waste that occurs is the DMAIC method. The factors causing waste can be determined and known by the DMAIC method at the analysis stage through the application of the Fishbone Diagram tool. From the results of the data processing carried out, here are the results of the waste-causing factors that were successfully analyzed and determined by the DMAIC method. 
Table 3 Results of the Analysis of the Factors Causing Waste with the DMAIC Method

\begin{tabular}{|c|c|}
\hline No & Factors that cause waste \\
\hline 1 & $\begin{array}{l}\text { The use of markers that are easily lost and damaged to mark the test area in } \\
\text { laboratory tests }\end{array}$ \\
\hline 2 & $\begin{array}{l}\text { Lack of customer knowledge of the importance of complaint sample } \\
\text { requirements }\end{array}$ \\
\hline 3 & The customer did not prepare a complaint sample as needed \\
\hline 4 & There is no form and guide for customers when making complaints \\
\hline 5 & $\begin{array}{l}\text { All work in laboratory tests for complaint handling is carried out by one lab. } \\
\text { Analyst }\end{array}$ \\
\hline 6 & $\begin{array}{l}\text { Lack of Lab Knowledge. Analyst regarding the required SEM test } \\
\text { magnification. }\end{array}$ \\
\hline 7 & There is a process with the same and repetitive activity content \\
\hline 8 & $\begin{array}{l}\text { Analysis based on data / information on complaints and laboratory test results } \\
\text { is carried out by the PIC simultaneously or simultaneously }\end{array}$ \\
\hline
\end{tabular}

From the analysis of the factors that cause waste that occurs using the DMAIC method, 8 factors that cause waste are determined in handling customer complaints in coil maker companies. The eight factors that cause the waste will be carried out an improvement plan, which will be used from the results of the improvement plan to determine the ideal time for handling customer complaints.

\section{Determination of the Ideal Time for Handling Customer Complaints}

By using the Value Stream Mapping method, especially the Future Value Stream Mapping (FVSM) which is integrated with the DMAIC method at the Improvement stage, the ideal time for handling customer complaints will be determined. Before determining the ideal time for handling customer complaints, a repair plan is carried out first of the factors that cause the waste that occurs. The following is a recapitulation of the repair plan on the factors that cause the waste that occurs.

Table 4 Design Improvements in Handling Customer complaints

\begin{tabular}{|c|c|}
\hline No & Rancangan Perbaiakan Pada Penanagan Keluhan Pelanggan \\
\hline 1 & $\begin{array}{l}\text { Melakukan sosialisasi berkala pada pelanggan menganai pentingnya kebutuhan dan } \\
\text { kelengkapan dari ketersediaan sample keluhan }\end{array}$ \\
\hline 2 & Pembuatan form dan panduan untuk pelanggan untuk melakukan keluhan \\
\hline 3 & $\begin{array}{l}\text { Pengunaan IT system perusahaan (Company Portal) untuk menghilangkan proses dengan } \\
\text { konten aktivitas yang sama dan dilakukan berulang }\end{array}$ \\
\hline 4 & $\begin{array}{l}\text { Melakukan sosialisasi berkala pada lab. Analyst mengenai kebutuhan perbesaran uji SEM } \\
\text { uang diperlukan }\end{array}$ \\
\hline 5 & Penggunaan scraber pen untuk marker are uji di test laboratorium \\
\hline 6 & $\begin{array}{l}\text { Penambahan lab. Analyst yang memiliki ijin perusahaan untuk test laboratorium untuk } \\
\text { pananganan keluhan pelanggan }\end{array}$ \\
\hline 7 & $\begin{array}{l}\text { Menghilang aktivitas berulang dan pembagian pekerjaan secara pararel untuk setiap PIC } \\
\text { pada Proses } 7\end{array}$ \\
\hline
\end{tabular}


The improvement design will have an impact on the complaints handling processes of customers. Prior to the improvement, there were nine processes in handling customer complaints, after the seven repair designs were carried out the process became seven processes for handling customer complaints. In addition to having an impact on the number of processes, the improvement design has an impact on improving the process time and lead time for handling customer complaints. Improvements to the process time and lead time will be used to determine the ideal time for handling customer complaints. The method used to determine the ideal time is the Value Stream Mapping (VSM) method, especially the Future Values Stream Mapping (FVSM) which is integrated with the DMAIC method at the Improvement stage. The results of the process time and lead time on FVSM show improvement when compared to CVSM. The following is a comparison of the process time and lead time between CVSM and FVSM.

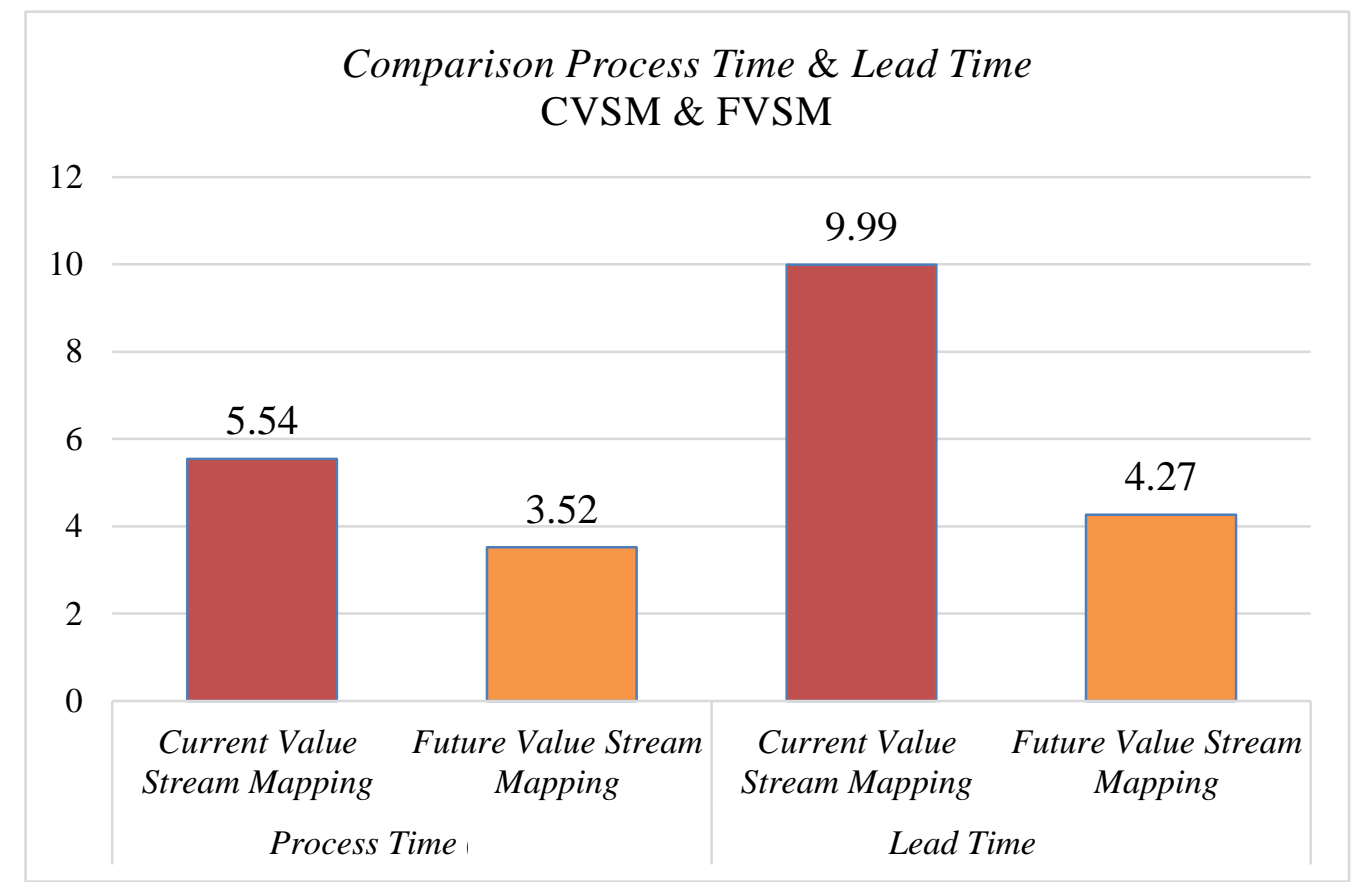

Figure 5 Comparison of CVSM \& FVSM Process Time \& Lead Time Improvement in Customer Complaint Handling

improvement in process time from 5.54 days to 3.52 days for FVSM and on lead time from 9.99 days to 4.27 days for FVSM. In FVSM, both the process time and lead time have reached the company's target in handling customer complaints, namely for 5 working days from the time the complaint is received until the complaint handling report is submitted to the customer. So that the ideal time for handling customer complaints is 4.27 days based on the improvement of the lead time which is done 0.82 days better than the company's target. Determination of the ideal time for handling complaints based on improved lead time because lead time has an understanding of the time it takes from the customer order is received until the product is received by the customer. In customer complaint handling, the intended order is a complaint made by a customer, while the product received by a customer is a customer complaint handling report. This has the same meaning as the target company, namely from the time the complaint is received until the complaint report is received by the customer.

Furthermore, the design of improvements that have been carried out will be standardized so that the ideal time that has been determined for handling customer complaints can be controlled. The standardization of the improvement design is carried out in the DMAIC method at the control stage, which aims to maintain and control the predetermined ideal time for handling customer complaints.

\section{CONCLUSION 6.1 Conclusion}

Based on observations and research on handling customer complaints at coil maker companies, here are the conclusions obtained from the research conducted:

1. Based on the results of the application of the integration of the DMAIC and WAM (Waste Assessment Model) methods of waste types and the weight of waste that occurs in handling customer complaints in coil maker companies, it can be seen, namely Defect (21.39\%), Inventory (17.64\%), Overproduction (16.44\%), Motion (15.26\%), Transportation (13.27\%), Waiting (11.06\%), and Process $(4.93 \%)$.

2. The factors that cause waste in handling customer complaints in coil maker companies can be determined by analyzing the DMAIC method's causes. Factors that cause waste that occurs are the use of missing and damaged markers for marking test areas in laboratory tests, lack of customer knowledge of the importance of complaint sample requirements; customers do not prepare complaint samples according to their needs, absence of forms and guidelines for customers when making complaints. , all work in 
laboratory tests for handling customer complaints is carried out by one lab: analyst, lack of lab knowledge. Analyst regarding the required SEM test magnification, a process with the same and repetitive activity content, and analysis based on data/information on complaints and laboratory test results are carried out by the PIC simultaneously or simultaneously.

3. Determining the ideal time to resolve customer complaints in coil maker companies by integrating DMAIC and VSM (Value Stream Mapping) methods.

In CVSM (Current Value Stream Mapping), handling customer complaints is 9.99 days based on a lead time with a processing time of 5.54 days. After repairing and making FVSM (Future Stream Mapping), the ideal time to resolve customer complaints is 4.27 days based on the lead time with a processing time of 3.52 days. Determination of the ideal time to resolve customer complaints, namely for 4.27 days, has reached the company's target of 5 days, even 0.82 days earlier than the target set by the company.

\subsection{Suggestion}

Based on the research conducted, the researcher provides several suggestions as input and consideration for both the company or subsequent research as follows:

1. Improvements are made to the study motion and re-layout in the laboratory area to make Motion in the laboratory. Analysts are more optimal and productive.

2. Calculation of costs or costs regarding equipment inventory and repairs carried out, as a matter of consideration of whether or not the improvement is feasible.

3. A continuous improvement process is carried out to be more optimal and productive.

4. Perform periodic evaluation of the standards that have been made and regular socialization of these standards.

\section{ACKNOWLEDGMENT}

Universitas Mercu Buana Research Centre funded this research. We are grateful for all experts who are willing to be research partners, with no mention of the company name.

\section{REFERENCES}

1. Adrianto, W., \& Kholil, M. (2016). Analisis Penerapan Lean Production Process untuk Mengurangi Lead Time Process Perawatan Engine (Studi Kasus PT.GMF AEROASIA). Jurnal Optimasi Sistem Industri, 14(2), 299. https://doi.org/10.25077/josi.v14.n2.p299-309.2015

2. Ashary, H., \& Jaqin, C. (2016). Reducing Downtime Equipment in LPM Machine Line Using DMAIC Approach at an Alloy Wheel Manufacturer in Indonesia. International Journal of Science and Research (IJSR), 5(7), 740-744. https://doi.org/10.21275/v5i7.art2016205

3. Barbosa, B., Pereira, M. T., Silva, F. J. G., \& Campilho, R. D. S. G. (2017). Solving Quality Problems in Tyre Production Preparation Process: A Practical Approach. Procedia Manufacturing, 11(June), $1239-1246$. https://doi.org/10.1016/j.promfg.2017.07.250

4. Gaspersz, V. (2007). Lean Six Sigma For Manufacturing and Service Industries. Gramedia Pustaka Utama.

5. Gryna, F. M. (2007). Juran's Quality Planning And Analysis For Enterprise Quality. McGraw-Hill Education.

6. Hines, P. P., \& Taylor, D. (2007). Going lean, Lean Enterprise Research Centre. MedGenMed: Medscape General Medicine.

7. Khannan, M. S. A., \& Haryono, H. (2017). Analisis Penerapan Lean Manufacturing untuk Menghilangkan Pemborosan di Lini Produksi PT Adi Satria Abadi. Jurnal Rekayasa Sistem Industri, $4(1), 47$. https://doi.org/10.26593/jrsi.v4i1.1383.47-54

8. Kholil, M., Haekal, J., Eko Adi Prasetio, D. ., \& Sulaiman Hasan. 2020. The Lean Manufacturing Design For Improving Production Scheduling Using Product Wheel Method in Chemical Manufacturing Company, Indonesia. International Journal of Engineering Research and Advanced Technology - IJERAT (ISSN: 2454-6135), 6(8), 12-18.

9. Haekal, J., \& Setio, H. 2017. Selection of Raw Material Suppliers Using Analytical Hierarchy Process in Food and Beverage Company, South Jakarta. ComTech: Computer, Mathematics and Engineering Applications, 8(2), 63-68.

10. Haekal, J. (2018). Perancangan Dan Evaluasi Implementasi Sistem Manajemen Mutu Iso 9001: 2015 Melalui Kepuasan Pelanggan Di Universitas Islam As-Syafi'iyah (Doctoral Dissertation, Universitas Mercu Buana Jakarta). 
11. Kholil, M., Haekal, J. H, Sulaiman. 2020. Lean Manufacturing Design to Reduce Waste in Gear Production Process Using VSM and Kaizen Method Approaches (Case Study: Gear Primary Driven K56 Product). Journal of Scientific and Engineering Research. 7(8), 1-9

12. Haekal, J., \& Prasetio, D. E. A. Planning Of Production Facilities Layouts In Home Industry With The Systematic Layout Planning Method.

13. haekal, J., \& Setiawan, I. (2020). Comparative Analysis of Raw Materials Control Using JIT and EOQ method For Cost Efficiency of Raw Material Supply in Automotive Components Company Bekasi, Indonesia. International Journal of Engineering Research and Advanced Technology (ijerat), 6(10), 76-82. https://doi.org/10.31695/IJERAT.2020.3661

14. Kholil, M., Hendri, Hanum, B., \& Setiawan, R. (2018). Using 7 waste approach and VSM method to improve the efficiency of mackerel fish crackers production time at small medium enterprise (SME). Proceedings of the International Conference on Industrial Engineering and Operations Management.

15. Marendra, I. G. (2018). Upaya Miminimasi Waste pada Lini Proses Produksi Kertas Memo Putar Menggunakan Value Stream Mapping (VSM). Operations Excellence, 10(1), 17-25.

16. Naro, A., \& Halimah, N. (2019). Perancangan Lean Production System Pada Lini Produksi Panel Listrik Tipe Wall Mounting Dengan. 8(1), 61-71.

17. Nugroho, A., Studi, P., Teknik, M., Buana, U. M., \& Service, L. (2017). Peningkatan Performa Kinerja Pelayanan Industri Telekomunikasi Menggunakan Filosofi Kaizen Dan Visual Stream Mapping Studi. 9(1), 13-26.

18. Pradana, A. P., Chaeron, M., \& Khanan, M. S. A. (2018). Implementasi Konsep Lean Manufacturing Guna Mengurangi Pemborosan Di Lantai Produksi. Opsi, 11(1), 14. https://doi.org/10.31315/opsi.v11i1.2196

19. Prasetyo, E., \& Kholil, M. (2014). Analisa Produksi Pada Aerosol Can $\varnothing 65$ X 124 Dengan Menggunakan Metode Pendekatan Six Sigma Pada Line Abm 3 Departemen Assembly Pt. Xyz. Jurnal PASTI, 8(2), 191-202.

20. Rawabdeh, I. A. (2005). A model for the assessment of waste in job shop environments. International Journal of Operations and Production Management, 800-822. https://doi.org/10.1108/01443570510608619

21. Rother, M., \& Shook, J. (2003). Learning to See Value Stream Mapping to Create Value and Eliminate Muda. Lean Enterprise Institute Brookline. https://doi.org/10.1109/6.490058

22. Kholil, M., Haekal, J., Prasetio, D. E. A., \& Hasan, S. (2020). The Lean Manufacturing Design for Improving Production Scheduling Using Product Wheel Method in Chemical Manufacturing Company, Indonesia.

23. Smętkowska, M., \& Mrugalska, B. (2018). Using Six Sigma DMAIC to Improve the Quality of the Production Process: A Case Study. Procedia - Social and Behavioral Sciences, 238, 590-596. https://doi.org/10.1016/j.sbspro.2018.04.039

24. Syukron, A., \& Kholil, M. (2012). Six Sigma Quality for Business Improvment (1st ed.). Graha Ilmu.

25. Lucia-Palacios, L., Perez-Lopez, R., \& Polo-Redondo, Y. (2020). How situational circumstances modify the effects of frontline employees' competences on customer satisfaction with the store. Journal of Retailing and Consumer Services, 52, 101905. 